\title{
The spider genus Rbysodromus Schick, 1965 in the Crimea (Aranei: Philodromidae)
}

\author{
Пауки рода Rbysodromus Schick, 1965 Крыма \\ (Aranei: Philodromidae)
}

\author{
Zoya A. Kastrygina ${ }^{1}$, Mykola M. Kovblyuk ${ }^{1,2}$ \\ 3.А. Кастрыгина ${ }^{1}$, Н.М. Ковблюк ${ }^{1,2}$
}

\footnotetext{
1'V.I. Vernadsky Crimean Federal University, Yaltinskaya Str. 4, Simferopol 295007, Crimea. E-mail: zoiac_21@mail.ru; kovblyuk@mail.ru ${ }^{2}$ T.I. Vyazemski Karadag Scientific Station - Nature Reserve of the Russian Academy of Sciences, Nauki Str., 24, Kurortnoe Vill., Feodosiya 298188, Crimea.

${ }^{1}$ Крымский федеральный университет им. В.И. Вернадского, ул. Ялтинская 4, г. Симферополь 295007, Крым.

${ }^{2}$ Карадагская научная станция им. Т.И. Вяземского - природный заповедник РАН, ул. Науки, 24, пос. Курортное, г. Феодосия 298188, Крым.
}

KEY WORDS: spiders, Rhysodromus, the Crimea, new records, new combinations, new synonym.

КЛЮЧЕВЫЕ СЛОВА: пауки, Rhysodromus, Крым, новые находки, новые комбинации, новый синоним.

ABSTRACT. Two species of Rhysodromus are recorded from the Crimea: $R$. fallax (Sundevall, 1833) and $R$. histrio (Latreille, 1819). R. fallax is reported for the Crimean fauna for the first time. Diagnostic drawings, distribution, spatial distribution and phenology for both species in the Crimea are provided. The validity and composition of the genus Rhysodromus are discussed. Here we suggest 24 new combinations: Rhysodromus ablegminus (Szita et Logunov, 2008), comb.n.; R. angulobulbis (Szita et Logunov, 2008), comb.n.; R. caspius (Ponomarev, 2008), comb.n.; $R$. cinerascens (O. Pickard-Cambridge, 1885), comb.n.; $R$. halophilus (Levy, 1977), comb.n.; R. hierosolymitanus (Levy, 1977), comb.n.; R. hierroensis (Wunderlich, 1992), comb.n.; $R$. hui (Yang et Mao, 2002), comb.n.; $R$. lanchowensis (Shenkel, 1936), comb.n.; $R$. lepidus (Blackwall, 1870), comb.n.; R. leucomarginatus (Paik, 1979), comb.n.; R. mysticus (Dondale et Redner, 1975), comb.n.; $R$. naxcivanicus (Logunov et Huseynov, 2008), comb.n.; R. omercooperi (Denis, 1947), comb.n.; R. petrobius (Schmidt et Krause, 1995), comb.n.; R. pictus (Kroneberg, 1875), comb.n.; R. rikhteri (Logunov, Huseynov, 2008), comb.n.; $R$. signatus (O. Pickard-Cambridge, 1869), comb.n.; R. sinaiticus (Levy, 1977), comb.n.; R. timidus (Szita et Logunov, 2008), comb.n.; R. triangulatus (Urita et Song, 1987), comb.n.; R. tuviensis (Szita et Logunov, 2008), comb.n.; $R$. xerophilus (Szita et Logunov, 2008), comb.n. and $R$. xinjiangensis (Szita et Logunov, 2008) comb.n.; all ex Philodromus. The species name Rhysodromus omercooperi (Denis, 1947) is synonymized with $R$. fallax (Sundevall, 1833). Thus, genus Rhysodromus now contains 26 valid species.

РЕЗЮМЕ. В Крыму зарегистрированы два вида рода Rhysodromus: R. fallax (Sundevall, 1833) и $R$. histrio (Latreille, 1819). R. fallax зарегистрирован впервые для фауны Крыма. Для обоих видов приводится диагностические рисунки, географическое распространение, биотопическая приуроченность и фенология. Обсуждается валидность и состав рода Rhysodromus. Установлены 24 новые комбинации: Rhysodromus ablegminus (Szita et Logunov, 2008), comb.n.; R. angulobulbis (Szita et Logunov, 2008), comb.n.; R. caspius (Ponomarev, 2008), comb.n.; $R$. cinerascens (O. Pickard-Cambridge, 1885), comb.n.; $R$. halophilus (Levy, 1977), comb.n.; R. hierosolymitanus (Levy, 1977), comb.n.; $R$. hierroensis (Wunderlich, 1992), comb.n.; R. hui (Yang et Mao, 2002), comb.n.; R. lanchowensis (Shenkel, 1936), comb.n.; $R$. lepidus (Blackwall, 1870), comb.n.; R. leucomarginatus (Paik, 1979), comb.n.; R. mysticus (Dondale et Redner, 1975), comb.n.; R. naxcivanicus (Logunov et Huseynov, 2008), comb.n.; R. omercooperi (Denis, 1947), comb.n.; $R$. petrobius (Schmidt et Krause, 1995), comb.n.; $R$. pictus (Kroneberg, 1875), comb.n.; R. rikhteri (Logunov, Huseynov, 2008), comb.n.; R. signatus (O. PickardCambridge, 1869), comb.n.; R. sinaiticus (Levy, 1977), comb.n.; R. timidus (Szita et Logunov, 2008), comb.n.; $R$. triangulatus (Urita et Song, 1987), comb.n.; $R$. tuviensis (Szita et Logunov, 2008), comb.n.; $R$. xerophilus (Szita et Logunov, 2008), comb.n. и $R$. xinjiangensis (Szita et Logunov, 2008) comb.n.; все ex Philodromus. Видовое название Rhysodromus omercooperi (Denis, 1947) синонимизировано с $R$. fallax (Sundevall, 1833). В результате, в род Rhysodromus помещено 26 валидных видов.

\section{Introduction}

This paper is a continuation of our studies on the Crimean philodromid spiders. Philodromidae Thorell, 1870 is a large family consisting of 30 genera and 542 species [WSC, 2016]. To date, two philodromid gen- 
era - Thanatus C.L. Koch, 1837 and Pulchellodromus Wunderlich, 2012 - have been reviewed in the Crimean fauna [Kastrygina, Kovblyuk, 2013, 2014]. The genus Philodromus Walckenaer, 1826 is the largest one in the family. At present, it includes 243 species, most of which are known from the Holarctic Region [WSC, 2016]. According to recent taxonomic studies [e.g., Muster, 2009b; Wunderlich, 2012], Philodromus is a paraphyletic taxon consisting of a large number of unrelated species that are characterized by the similar general appearance only. Recently, Philodromus was subdivided by Wunderlich [2012] into several distinct genera, as listed by Kastrygina, Kovblyuk [2014: Table 1]. Of them, only the genus Pulchellodromus has been reviewed in the Crimean fauna [Kastrygina, Kovblyuk, 2014]. In the present paper, we are providing new faunistic records and diagnostic drawings for the two species of genus Rhysodromus Schick, 1965 from the Crimea. The taxonomic status and composition of the genus are also discussed.

\section{Material and methods}

All the specimens treated in this study are shared between the National Arachnological Collection of the V.I. Vernadsky Taurida National University, Simferopol, the Crimea, curator M.M. Kovblyuk (TNU) and the Zoological Museum of the Moscow State University, Moscow, curator K.G. Mikhailov (ZMMU). In the material reported below the name of the collector M.M. Kovblyuk is abbreviated as M.K.

Drawings were made under both stereoscopic and brightfield microscopes by using a grid method. Illustrations of the epigynes were made after maceration in $\mathrm{KOH} 20 \%$ water solution. All scale bars are $0.1 \mathrm{~mm}$, except for general appearances and carapace frontal views where the scale bars are $1 \mathrm{~mm}$.

The morphological terminology follows Almquist [2006], Muster et al. [2007], Muster [2009a,b] and Wunderlich [2012]. Abbreviations used in the text and figure plates are as follows. Pedipalp: $C$ - conductor; $C y$ - cymbium; $E$ - embolus; $E O$ - origin of embolus; PTA - philodromid tegular apophysis; RTA retrolateral tibial apophysis; $S D$ - sperm duct loop; $S T$ - subtegulum; Te - tegulum; VTA - ventral tibial apophysis. Epigyne: $B C$ - bursa copulatrix; $C o-$ copulatory opening; $E G$ - epigynal groove; $F D$ - fertilisation duct; $G H$ - glandular head; $G M$ - glandular mound; $M S$ - median septum; $R$ - receptaculum.

In the text we have provided references to the most important publications only. For a complete set of taxonomic references see WSC [2016].

\section{Taxonomic survey}

\section{Genus Rhysodromus Schick, 1965}

Type species: Thomisus histrio Latreille, 1819.

The neglected genus Rhysodromus is a well-defined taxon within the Philodromidae (usually, as the histrio species group) [see Schick, 1965; Dondale, Redner, 1975; Szita, Logunov, 2008; Muster, 2009a,b; Wunderlich, 2012]. In our opinion, a re-elevation of Rhysodromus to the genus of its own is highly justified and is therefore accepted here.

DIAGNOSIS. Although there is no singular character that could distinguish Rhysodromus from other (sub)genera and species groups currently included in the large paraphyletic genus Philodromus [sensu lato; e.g., Dondale, Redner, 1975], the following combination of characters is indeed unique and diagnostic: metatarsus I usually bears 2 pairs of ventral spines, of which the second pair is situated in the middle of the segment or more basally; leg II moderately elongated, at most 1,4 times as long as leg I; the embolus stout, frequently straight, situated at the top of the tegulum; leg scopulae dense, especially in females [see Szita, Logunov, 2008; Muster, 2009b; Wunderlich, 2012].

DESCRIPTION. The genus was described by Schick [1965: 67]. A detailed redescription of the genus (sub the histrio species group) was provided by Szita \& Logunov [2008].

COMMENTS. The recent cladistic analysis of the Philodromidae [see Muster, 2009ab] showed that Rhysodromus (sub the histrio species group) is more closely related to Thanatus C. L. Koch, 1837 and Tibellus Simon, 1875 than to other species groups and (sub)genera of Philodromus (sensu lato).

COMPOSITION. In the Nearctic Region, the taxon is represented by three species [Schick, 1965; Dondale, Redner, 1975] (see Table 1). Szita, Logunov [2008] included 16 species from the eastern Palaearctic in Rhysodromus (sub the histrio species group). Yet, Muster [2009b] transferred the species Ebo halophilus Levy, 1977 to the histrio species group. Wunderlich [2012] included 13 species in Rhysodromus. In addition, many Rhysodromus species seem to occur in the Mediterranean and northern Africa, but these are in need of a taxonomic revision [see Muster, 2009b].

Based on conformation of the copulatory organs, some other species of the histrio species group are to be transferred from Philodromus to Rhysodromus, with 24 new combinations being proposed here: Rhysodromus ablegminus (Szita et Logunov, 2008), R. angulobulbis (Szita et Logunov, 2008), R. caspius (Ponomarev, 2008), $R$. cinerascens (O. Pickard-Cambridge, 1885), R. halophilus (Levy, 1977), R. hierosolymitanus (Levy, 1977), R. hierroensis (Wunderlich, 1992), $R$. hui (Yang et Mao, 2002), R. lanchowensis (Shenkel, 1936), R. lepidus (Blackwall, 1870), R. leucomarginatus (Paik, 1979), R. mysticus (Dondale et Redner, 1975), $R$. naxcivanicus (Logunov et Huseynov, 2008), R. omercooperi (Denis, 1947), R. petrobius (Schmidt et Krause, 1995), R. pictus (Kroneberg, 1875), R. rikhteri (Logunov et Huseynov, 2008), R. signatus (O. PickardCambridge, 1869), R. sinaiticus (Levy, 1977), R. timi$d u s$ (Szita, Logunov, 2008), $R$. triangulatus (Urita et Song, 1987), R. tuviensis (Szita et Logunov, 2008), $R$. xerophilus (Szita et Logunov, 2008) and $R$. xinjiangensis (Szita et Logunov, 2008); all comb.n. ex Philo- 
Table 1. Valid species of Rhysodromus Schick, 1965 and their distribution. Таблица 1. Валидные виды рода Rhysodromus Schick, 1965 и их распространение.

\begin{tabular}{|c|c|c|}
\hline No & Species & Distribution \\
\hline 1 & $\begin{array}{l}\text { R. ablegminus (Szita et Logunov, } \\
\text { 2008), comb.n. }\end{array}$ & Kazakhstan (Almaty and Zhambyl areas) \\
\hline 2 & R. alascensis (Keyserling, 1884) & Holarctic temperate range (Siberia and North America) \\
\hline 3 & $\begin{array}{l}\text { R. angulobulbis (Szita et Logunov, } \\
\text { 2008), comb.n. }\end{array}$ & $\begin{array}{l}\text { Russia (mountains of South Siberia: Tuva, Gorno-Altai } \\
\text { Republic, Chita Region) }\end{array}$ \\
\hline 4 & $\begin{array}{l}\text { R. caspius (Ponomarev, 2008), } \\
\text { comb.n. }\end{array}$ & $\begin{array}{l}\text { Russia (Kalmykia), Kazakhstan (Atyrau and West-Kazakhstan } \\
\text { areas) }\end{array}$ \\
\hline 5 & $\begin{array}{l}\text { R. cinerascens (O. Pickard- } \\
\text { Cambridge, 1885), comb.n. }\end{array}$ & China (Xinjiang, Yarkand) \\
\hline 6 & R. fallax (Sundevall, 1833) & Trans-Palaearctic temperate range \\
\hline 7 & R. halophilus (Levy, 1977), comb.n. & Israel \\
\hline 8 & $\begin{array}{l}\text { R. hierosolymitanus (Levy, 1977), } \\
\text { comb.n. }\end{array}$ & Israel, the UAE, Iran \\
\hline 9 & $\begin{array}{l}\text { R. hierroensis (Wunderlich, 1992), } \\
\text { comb.n. }\end{array}$ & The Canary Islands \\
\hline 10 & R. histrio (Latreille, 1819) & Circum-Holarctic temperate range \\
\hline 11 & R. hui (Yang et Mao, 2002), comb.n. & China (Yunnan) \\
\hline 12 & $\begin{array}{l}\text { R. lanchowensis (Schenkel, 1936), } \\
\text { comb.n. }\end{array}$ & $\begin{array}{l}\text { East-Palaearctic subboreal range (Siberia and Far East of } \\
\text { Russia, China, Korea, Japan) }\end{array}$ \\
\hline 13 & $\begin{array}{l}\text { R. lepidus (Blackwall, 1870), } \\
\text { comb.n. }\end{array}$ & $\begin{array}{l}\text { Spain, France, Corsica, Italian mainland, Sicily, Macedonia, } \\
\text { Romania, southern European Russia, Armenia, Turkmenistan, } \\
\text { India. The published records from outside the Mediterranean } \\
\text { needs confirmation upon the pertinent material, as no good } \\
\text { drawings and detailed (re)descriptions of these species are } \\
\text { available in recent literature. }\end{array}$ \\
\hline 14 & $\begin{array}{l}\text { R. leucomarginatus (Paik, 1979), } \\
\text { comb.n. }\end{array}$ & China (Inner Mongolia, Shanxi, Shandong), Korea \\
\hline 15 & $\begin{array}{l}\text { R. mysticus (Dondale et Redner, } \\
\text { 1975), comb.n. }\end{array}$ & Holarctic temperate range (Siberia and North America) \\
\hline 16 & $\begin{array}{l}\text { R. naxcivanicus (Logunov et } \\
\text { Huseynov, 2008), comb.n. }\end{array}$ & Azerbaijan (Naxcivan) \\
\hline 17 & $\begin{array}{l}\text { R. petrobius (Schmidt et Krause, } \\
\text { 1995), comb.n. }\end{array}$ & Cape Verde Islands \\
\hline 18 & $\begin{array}{l}\text { R. pictus (Kroneberg, 1875), } \\
\text { comb.n. }\end{array}$ & $\begin{array}{l}\text { Turanian subboreal range: Uzbekistan (Kopetdagh), } \\
\text { Tadjikistan, Kirghizia, Kazakhstan (Almaty Area), China } \\
\text { (Xinjiang) }\end{array}$ \\
\hline 19 & $\begin{array}{l}\text { R. rikhteri (Logunov et Huseynov, } \\
\text { 2008), comb.n. }\end{array}$ & Armenia \\
\hline 20 & $\begin{array}{l}\text { R. signatus (O. Pickard-Cambridge, } \\
\text { 1869), comb.n. }\end{array}$ & St. Helena Island \\
\hline 21 & R. sinaiticus (Levy, 1977), comb.n. & Israel \\
\hline 22 & $\begin{array}{l}\text { R. timidus (Szita et Logunov, 2008), } \\
\text { comb.n. }\end{array}$ & $\begin{array}{l}\text { Russia (Daghestan), Kazakhstan (Atyrau and Almaty areas), } \\
\text { Pakistan (Korakoram) }\end{array}$ \\
\hline 23 & $\begin{array}{l}\text { R. triangulatus (Urita et Song, } \\
\text { 1987), comb.n. }\end{array}$ & $\begin{array}{l}\text { Central Asian subboreal range: Kazakhstan (Almaty Area), } \\
\text { Kirghizia, Russia (Tuva), Mongolia, China (Inner Mongolia) }\end{array}$ \\
\hline 24 & $\begin{array}{l}\text { R. tuviensis (Szita et Logunov, } \\
\text { 2008), comb.n. }\end{array}$ & $\begin{array}{l}\text { Kazakhstan (Pavlodar Area), Russia (the mountain Altai and } \\
\text { Tuva), Mongolia }\end{array}$ \\
\hline 25 & $\begin{array}{l}\text { R. xerophilus (Szita et Logunov, } \\
\text { 2008), comb.n. }\end{array}$ & $\begin{array}{l}\text { Russia (Buryatia, Chita Region, Tuva), Kazakhstan (Almaty } \\
\text { Area) }\end{array}$ \\
\hline 26 & $\begin{array}{l}\text { R. xinjiangensis (Szita et Logunov, } \\
\text { 2008), comb.n. }\end{array}$ & $\begin{array}{l}\text { Central Asian subboreal range: Azerbaijan, Kazakhstan (Kzyl- } \\
\text { Orda and Almaty areas), Turkmenistan, Uzbekistan, China } \\
\text { (Xinjiang, Inner Mongolia) }\end{array}$ \\
\hline
\end{tabular}


dromus. Thus, in total, 26 valid species are currently included in the genus Rhysodromus (see Table 1). The genus Rhysodromus is likely to be even more diverse. Many poorly known species have been described in the genus Philodromus (sensu lato) without any illustration, remain known from the females only, or lack good differential diagnoses or without a comparison with the related species, are likely to need transferring to Rhysodromus as well. The matter requires further attention in the future.

DISTRIBUTION. Rhysodromus species are known from the coast of Arctic Ocean and Arctic islands in the noth, southward to Cape Verde and St. Helena Islands, Egypt, Israel, the UAE, Iran, Korakoram in Pakistan and Yunnan in China; there are also three Nearctic species.

HABITAT. European species are ground and grass dwellers of sandy areas and coastal dunes, steppes, salt marshes, and in forest glades [Krasnobaev, 2004; Szita, Logunov, 2008; Wunderlich, 2012; present data]. Habitat preferences for the species from the Caucasus, northern and central Asia are described in detail by Logunov, Huseynov [2008] and Szita, Logunov [2008].

\section{Review of the Crimean species}

Rhysodromus fallax (Sundevall, 1833)

Figs 4-14, 17-20, 22, 24-25.

Philodromus omercooperi Denis, 1947: 56, pl. 3, fig. $4\left(\sigma^{7}\right.$ holotype from Shiata, Egypt, not examined), syn.n.

Philodromus f: Szita, Logunov, 2008: 55, figs 47-49, 59-60, $78\left(\sigma^{7}+\right)$

RECORDS FROM THE CRIMEA. Kastrygina, Kovblyuk [2015: sub Rhysodromus omercooperi (Denis, 1947)] is a misidentification; the material re-examined.

MATERIAL. UKRAINE. The Crimea: Lenino Distr.: $10^{7}, 4$ 우 (TNU), environs Aktash lake, swipping, 7.06.1999, M.K.; Razdol'noe Distr.: 1 + (TNU), kosa nr. Portovoe Vil., 20.08.1998, V.N. Popov; 1 \& (TNU-2241/4), Andreevskaya kosa, nr. Portovoe Vil., 2226.06.2006, E.Yu. Sviridenko; Saky Distr.: $1 O^{7}$ (TNU-1579/5), vicinity of Pribrezhnaya railway station, Salocornia europaea, $\mathrm{Ha}$ locnemum strobilaceum, 10 pitfalls, 19-28.07.2000, M.K.; Kherson Area: Genichesk Distr., Arabatskaya strelka, sand: $1 \mathrm{O}^{\top}$ (TNU-2806 2), c. $5 \mathrm{~km} \mathrm{~S}$ of Genichesk, $30 \mathrm{~m}$ of the sea coast, Phragmites, 14.07.2010, N.A. Stasyuk; 1 + (TNU-2792/2), same locality, $20 \mathrm{~m}$ of the sea coast, Phragmites, 24.07.2010, N.A. Stasyuk; 1 + (TNU2794/3/1), same locality, Phragmites, 15.08.2010, N.A. Stasyuk; 1 O' (TNU-2895/3), c. $2,5 \mathrm{~km} \mathrm{~S}$ of Strelkovoe Vil., 24.04.2011, N.A. Stasyuk; 1 (TNU-2889/2), $4 \mathrm{~km} \mathrm{~S}$ from Genichesk, $40 \mathrm{~m}$ of the sea coast, swipping, 7.09.2011, N.A. Stasyuk; $1 O^{7}, 1$ (TNU-3144/1), same locality, $50 \mathrm{~m}$ of the sea coast, swipping, 14.05.2012, N.A Stasyuk; 1 (TNU-3123/2), same locality, swipping, 28.05.2012, N.A. Stasyuk; 1 (TNU-3111/4), same locality, 4.06.2012, N.A. Stasyuk; $2 O^{7} \sigma^{7}, 2$ 우 (ZMMU from TNU-3143/3), same locality, 18.06.2012, N.A. Stasyuk; $2 \bigcirc^{7} \sigma^{7}$ (TNU-3130/4), same locality, 20 $\mathrm{m}$ of the sea coast, salt-marsh, swipping, 18.06.2012, N.A. Stasyuk; $1 \mathrm{O}^{7}, 2$ 우 (TNU-3142/2), same locality, $20 \mathrm{~m}$ of the sea coast, swipping, 18.06.2012, N.A. Stasyuk; 1 (TNU-3150/1), same locality, $200 \mathrm{~m}$ of the sea coast, salt-marsh, swipping, 25.06.2012, N.A. Stasyuk; $1 \mathrm{O}^{7}, 5$ OP (TNU-3153/1), same locality, $50 \mathrm{~m}$ of the sea coast, swipping, 25.06.2012, N.A. Stasyuk; 1 O (TNU-3155/2), same locality, $20 \mathrm{~m}$ of the sea coast, swipping, 25.06.2012, N.A. Stasyuk; 1 (TNU-3116/2/1), same locality, $200 \mathrm{~m}$ of the sea coast, salt-marsh, swipping, 30.06.2012, N.A. Stasyuk; 2 우 (TNU$3147 / 1$ ), same locality, $200 \mathrm{~m}$ from sea coast, salt-marsh, swipping, 2.07.2012, N.A. Stasyuk; 1 ア , 5 क् (TNU-3149/2), same locality, $50 \mathrm{~m}$ of the sea coast, swipping, 2.07.2012, N.A. Stasyuk; $1 \mathrm{\sigma}^{7}, 2$ 우 (TNU-3152/2), same locality, $20 \mathrm{~m}$ of the sea coast, swipping, 2.07.2012, N.A. Stasyuk.

DIAGNOSIS. $R$. fallax is most similar to $R$. angulobulbis [Szita, Logunov, 2008], but can be distinguished by the following characters: 1) the embolic shape (saddle-shaped distally in $R$. fallax and more or less straight in $R$. angulobulbis); 2) the shape of VTA (with a tip cut in $R$. fallax and more or less pointed in $R$. angulobulbis); 3 ) the width of the epigynal groove (wider in $R$. fallax); 4) the position of glandular head (dorsal in $R$. fallax and more or less ventral in $R$. angulobulbis).

DESCRIPTION. Male $(\mathrm{n}=3)$. Measurements. Diameter of AME 0.12-0.15. Diameter of ALE 0.090.12. Clypeal height im AME 0.18-0.36. Clypeal height im ALE 0.24-0.40. Ratio between clypeal height im AME and diameter of AME is 1.3-2.4. Ratio between clypeal height im ALE and diameter of ALE is 2.7-3.4. Female $(\mathrm{n}=2)$. Measurements. Diameter of AME 0.150.16. Diameter of ALE 0.12. Clypeal height im AME 0.27-0.28. Clypeal height im ALE 0.32-0.34. Ratio between clypeal height im AME and diameter of AME is 1.6-1.9. Ratio between clypeal height im ALE and diameter of ALE is 2.6-2.9. The species is described in detail by Szita, Logunov [2008: sub Philodromus f.].

COMMENTS. The male of Philodromus omercooperi Denis, 1947 from Egypt is well described and illustrated by Denis [1947]; its female remains unknown. P. omercooperi has never been recorded and/ or redescribed after its original description. In his remark after the description Denis [1947: 56] compared this species with $P$. fallax, the member of the genus Rhysodromus, therefor we have proposed a new combination: Rhysodromus omercooperi (Denis, 1947) comb.n., ex Philodromus.

In his description, Denis [1947: 56] mentioned that "the tibial apophysis of the palp of this species closely resembles that of $P h$. fallax Sund., but the bulb is quite different". We have examined numerous males of $R$. fallax from the Crimea and Arabatrskaya strelka (see the Material studied) and revealed a high degree of variability in the shape of embolus and conductor (see Figs 5, 8, 11). Denis's drawing [Denis, 1947: pl. 3, f. 4] well fit into this variations (see Fig. 14).

In addition, Denis [1947: 56] mentioned that "anterio-lateral eyes equalling in size $2 / 3$ of the diameter of the anterio-median eyes". We have studied several males of $R$. fallax and revealed a great variation in the size of anterior eyes (see the Description and Figs 17-18). Thus, this character of $P$. omercooperi lies within the variation limits of $R$. fallax as well.

No other sufficient differences of $R$. omercooperi from $R$. fallax were provided by Denis [1947]. Therefore, it is safe to conclude that the species name $R$. omercooperi (Denis, 1947) is to be synonymized with R. fallax. 

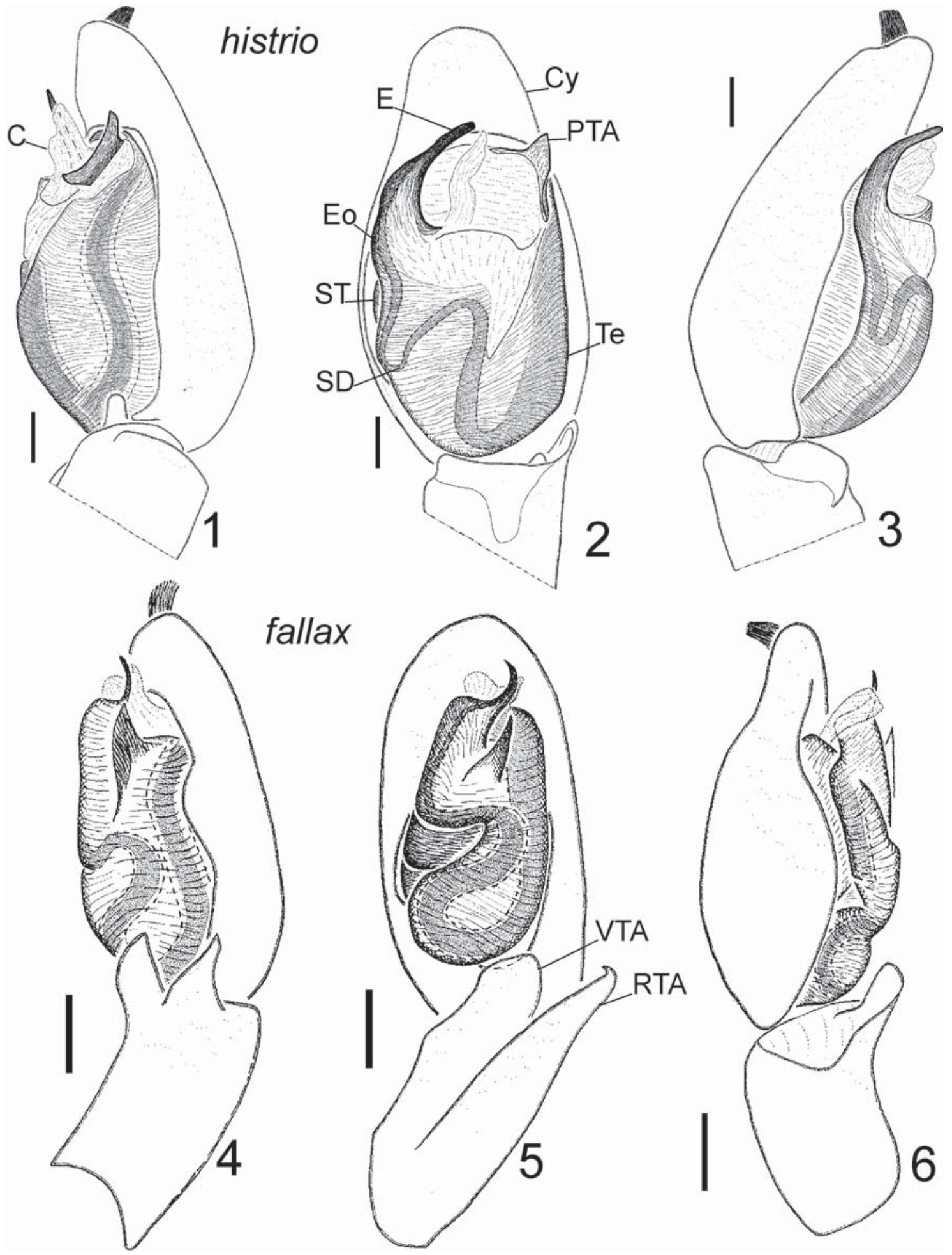

Figs 1-6. Male palps of Rhysodromus histrio (Latreille, 1819) (1-3) and R. fallax (Sundevall, 1833) (4-6): 1, 4 - retrolateral view; 2, 5 - ventral view; 3,6 - prolateral view. Scale bars: $0.1 \mathrm{~mm}$.

Abbreviations: $C$ - conductor; $C y$ - cymbium; $E$ - embolus; $E O$ - origin of embolus; $P T A$ - philodromid tegular apophysis; $R T A$ - retrolateral tibial apophysis; $S D$ - sperm duct loop; $S T$ - subtegulum; Te — tegulum; VTA — ventral tibial apophysis.

Рис. 1-6. Пальпы самцов Rhysodromus histrio (Latreille, 1819) (1-3) и R. fallax (Sundevall, 1833) (4-6): 1, 4 - вид ретролатерально; 2, 5 - вид вентрально; 3, 6 - вид пролатерально. Масштаб: 0,1 мм.

Обозначения: $C$ - кондуктор; $C y$ - цимбиум; $E$ - эмболюс; $E o-$ основание эмболюса; $P T A-$ филодромидный тегулярный отросток; $R T A$ - ретролатеральный отросток голени; $S D$ - петля семенного канала; $S T$ — субтегулюм; Te — тегулюм; VTA вентральный отросток голени. 

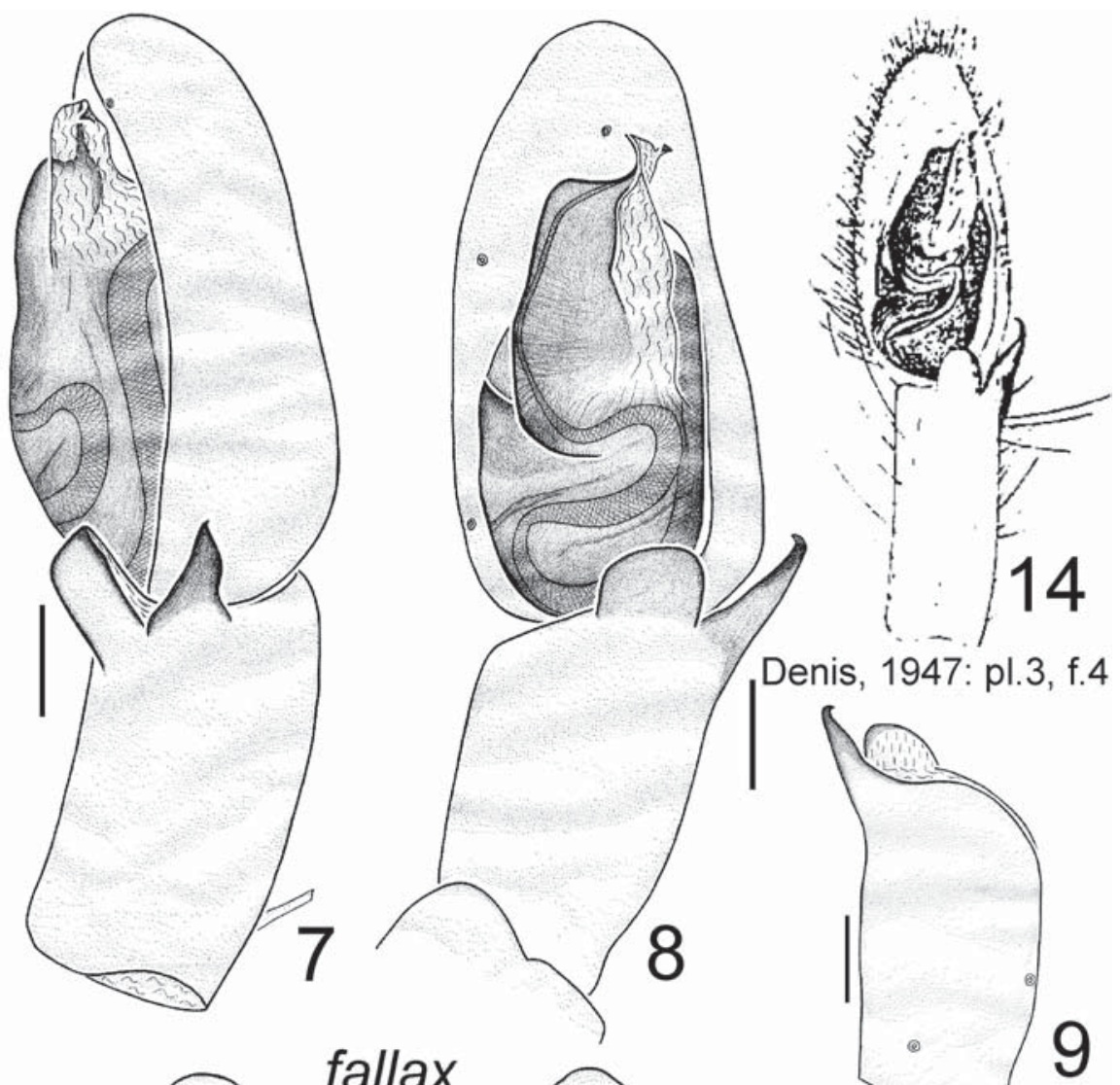

Denis, 1947: pl.3, f.4
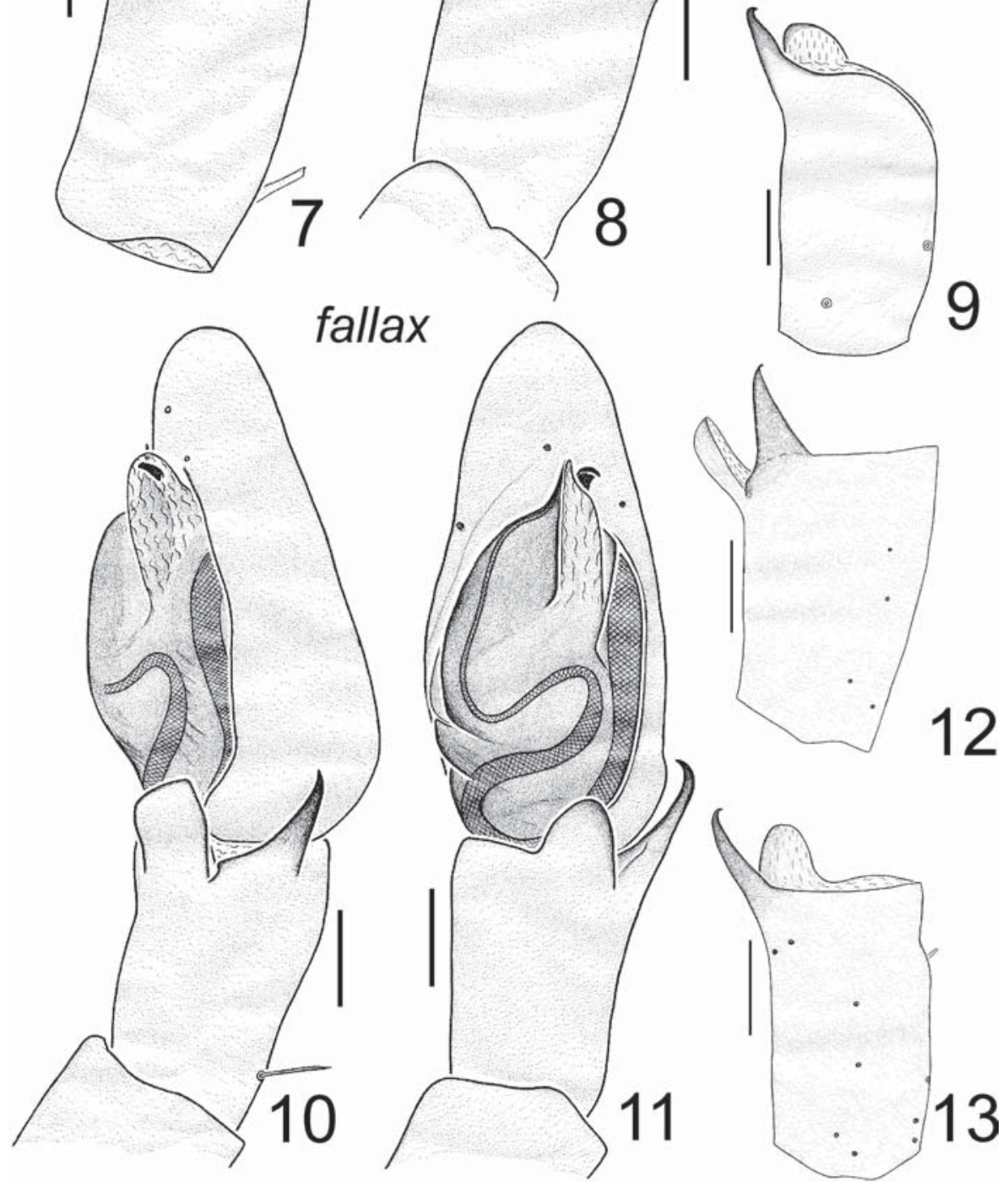

Figs 7-14. Male palp variation of Rhysodromus fallax (Sundevall, 1833): 7, 10 - retrolateral view; 8, 11, 14 — ventral view (14 after Denis [1947]); 9, 13 - tibia, dorso-retrolateral view; 12 - tibia, retro-dorsal. Scale bars: $0.1 \mathrm{~mm}$.

Рис. 7-14. Изменчивость пальпы самцов Rhysodromus fallax (Sundevall, 1833): 7, 10 - вид ретролатерально; 8, 11, 14 - вид вентрально (14 - по: Denis [1947]); 9, 13 — голень, вид дорсо-ретролатерально; 12 - голень ретро-дорсально. Масштаб: 0,1 мм. 

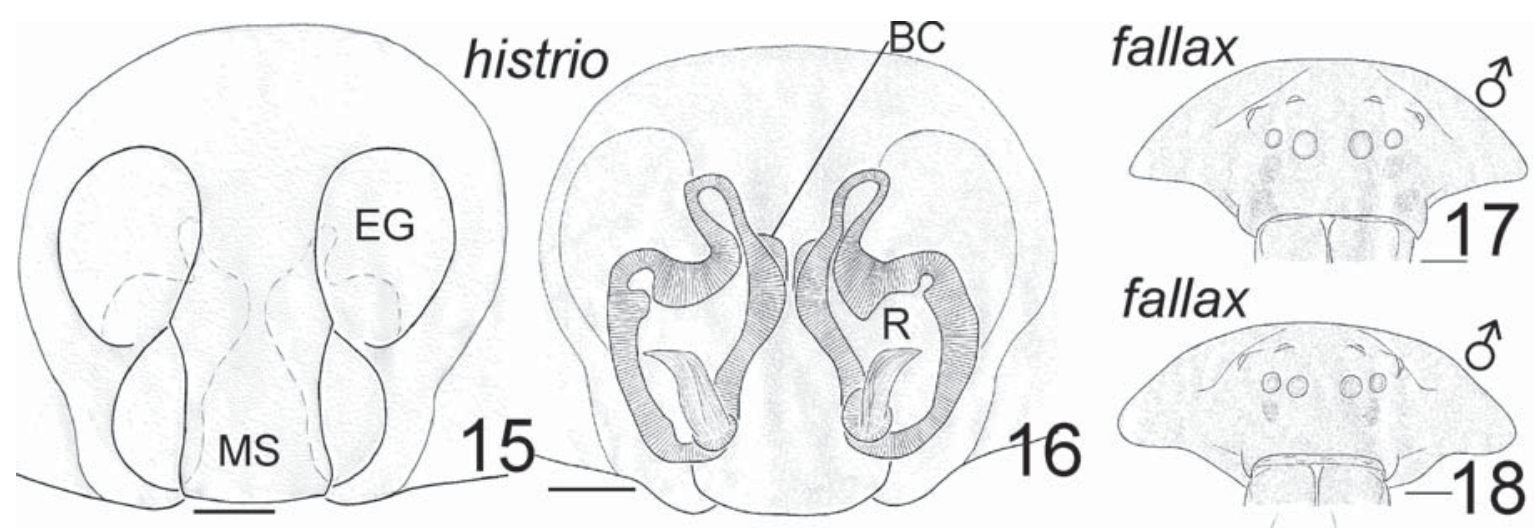

fallax
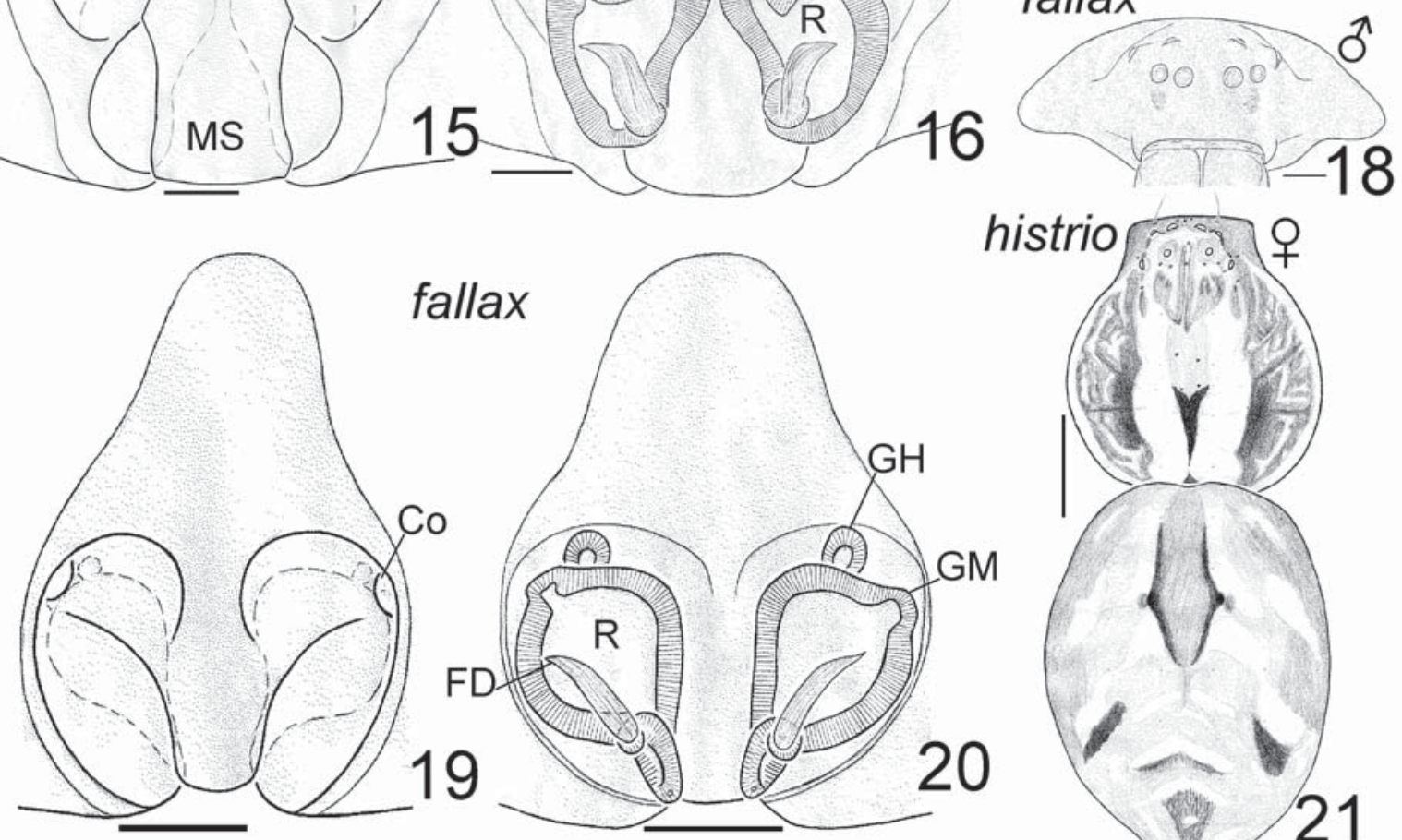

histrio
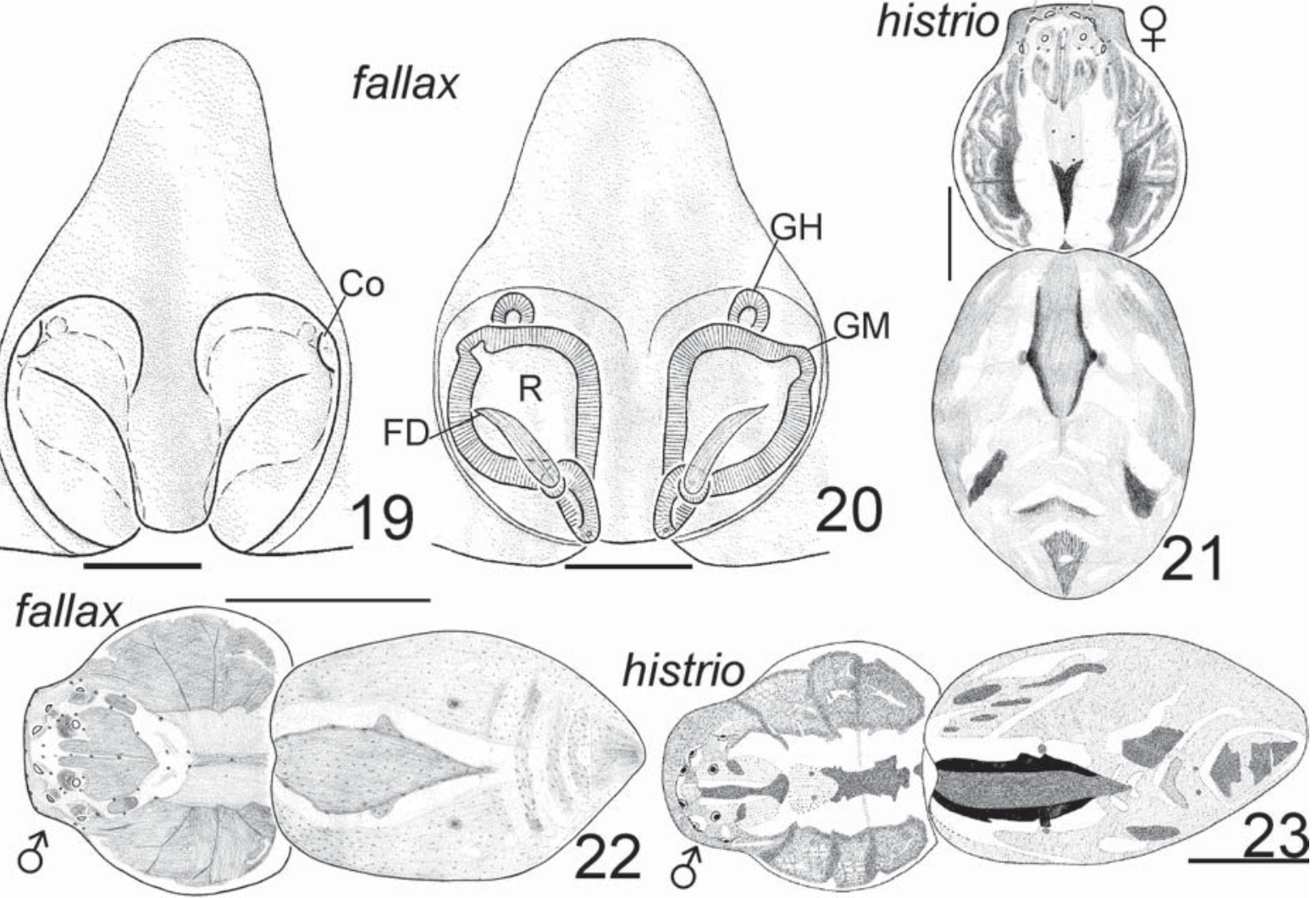

Figs 15-23. Epigyne, carapace and habitus of Rhysodromus histrio (Latreille, 1819) (15-16, 21, 23) and R. fallax (Sundevall, 1833) (17-20, 22): 15, 19 - epigyne, ventral view; 16, 20 - epigyne, dorsal view; 17-18 - carapace, frontal views (variations); 21-23 habitus, dorsal views. Scale bar: $0.1 \mathrm{~mm}(15-16,19-20), 1 \mathrm{~mm}(17-18,21-23)$.

Abbreviations: $B C$ - bursa copulatrix; $C o$ - copulatory opening; $E G$ - epigynal groove; $F D$ - fertilisation duct; $G H-$ glandular head; $G M$ - glandular mound; $M S$ - median septum; $R$ - reseptaculum.

Рис. 15-23. Эпигины, карапаксы и габитусы Rhysodromus histrio (Latreille, 1819) (15-16, 21, 23) и R. fallax (Sundevall, 1833) (17-20, 22): 15, 19 - эпигины, вид вентрально; 16, 20 - эпигины, вид дорсально; 17-18 - карапаксы, вид фронтально; 21-23 — габитусы, вид дорсально. Масштаб: 0,1 мм (15-16, 19-20), 1 мм (17-18, 21-23).

Обозначения: $B C$ - копулятивная сумка; $C o-$ копулятивное отверстие; $E G$ - ямка эпигины; $F D-$ оплодотворительный канал; $G H$ - головка железы; $G M$ - железистый бугорок; $M S$ - медиальный септум; $R$ - рецептакула.

Recently, we erroneously recorded $R$. omercooperi from Arabatskaya strelka [Kastrygina, Kovblyuk, 2015]. This record resulted from a misidentification of $R$. fallax (the material - one male with the collection number TNU-2895/3 — has been re-examined).

DISTRIBUTION. Trans-Palearctic polyzonal range [Szita, Logunov, 2008; Helsdingen, 2013; Mikhailov,
2013; Nentwig et al., 2016; present data]. Egypt [Denis, 1947: sub Philodromus omercooperi] and Iran [Logunov et al., 2007: sub Philodromus f.] are the southernmost records of the species range. This species is recorded from the Crimea for the first time.

HABITATS. Sandy steppes, semi-deserts and saltmarshes. 


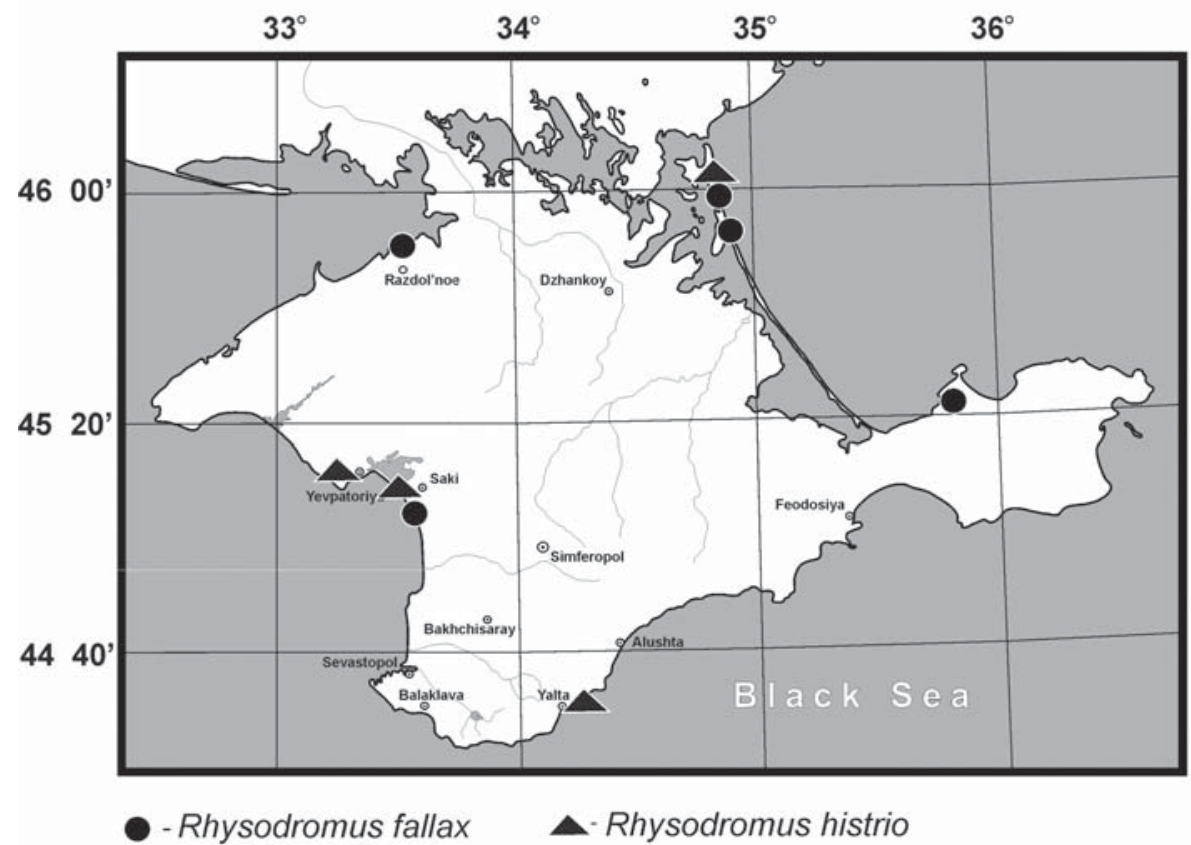

Fig. 24. Distribution maps of Rhysodromus fallax (Sundevall, 1833) and R. histrio (Latreille, 1819) in the Crimea based on the collected specimens.

Рис. 24. Карта распространения Rhysodromus fallax (Sundevall, 1833) и R. histrio (Latreille, 1819) в Крыму по материалам коллекции.
PHENOLOGY. The Crimea $\sigma^{\top} \sigma^{\top}-$ IV-VII, + + $\mathrm{V}-\mathrm{IX}$, the peak activity of adults occurs in June (Fig. 25). Great Britain: $\sigma^{\top} \sigma^{\top}-\mathrm{IV}-\mathrm{V}$,, $0+\mathrm{IV}-\mathrm{VI}[\mathrm{Har}-$ vey et al., 2002]. Sweden: $\sigma^{\top} \sigma^{\top}-\mathrm{V}-\mathrm{VI},+$ o+ $-\mathrm{V}-$ VIII [Almquist, 2006]. Azerbaijan: $\sigma^{7} \sigma^{7}-\mathrm{V}-\mathrm{VI}$, o̊ — - V-VI [Szita, Logunov, 2008].

\section{Rhysodromus histrio (Latreille, 1819)}

Figs 1-3, 15-16, 21, 23-25.

Philodromus h.: Dondale, Redner, 1975: 373, figs 10-25 ( $\sigma^{7}+$ ). Philodromus $h$.: Urones, 1986: 235, figs 4a-e ( $\left.\sigma^{7}+\right)$.

Philodromus h.: Paquin, Dupérré, 2003: 180, figs 1995-1998 $\left(\mathrm{O}^{7}+\right)^{2}$. $\left(\sigma^{\top}+\right.$ P).

Philodromus h.: Szita, Logunov, 2008: 29, figs 2-6, 16-17, 67

RECORDS FROM THE CRIMEA. Spassky [1927]; Charitonov [1932]; Bragina [1984]; Mikhailov [1997, 1998, 2000]; Kovblyuk [2004a,b]; Kovblyuk et al. [2008]; Szita, Logunov [2008]; Mikhailov [2013]; Kovblyuk, Kastrygina [2015]; Kovblyuk et al. [2015].

MATERIAL. UKRAINE. The Crimea: Saky Distr.: 1 o (ZMMU), Evpatoriya, in the grass, 4.05.1997, G.V. Reutov; 1 o (ZMMU from TNU-1654/9), vicinity of Pribrezhnaya railway station, Artemisia on sand, 10 pitfalls, 30.04-9.05.2000, M.K.; Yalta Distr.: 1 + (TNU-1306/9/1), c. $1 \mathrm{~km} \mathrm{~N}$ from Nikita Vil., neglected field, 10 pitfalls, 27.05.-3.06.2000, M.K.; Kherson Area: Genichesk Distr., Arabatskaya strelka, sand: 2 오 (TNU-2799/8), c. 7 $\mathrm{km} \mathrm{S}$ of Genichesk, $20 \mathrm{~m}$ of the sea coast, Artemisia, 6.07.2010, N.A. Stasyuk; 2 우 (TNU-3153/2), 4 km S from Genichesk, $50 \mathrm{~m}$ of the sea coast, swipping, 25.06.2012, N.A. Stasyuk; 1 O$^{7}$ (TNU3149/1), same locality, 2.07.2012, N.A. Stasyuk.

DIAGNOSIS. $R$. histrio is most similar to $R$. ablegminus and R. xerophilus [cf. Szita, Logunov, 2008], but can be distinguished by the following characters: 1) the thickness of the embolus (thickest in R. histrio);2) the shape of philodromid tegular apophysis (with two peaks in $R$. histrio and one peak in $R$. ablegminus and
R. xerophilus); 3) the width of the median septum of epigyne (the central and basal parts are almost equal in their width in $R$. histrio, the central part is wider than the basal one in $R$. ablegminus, and the central parts is narrower than the basal one in $R$. xerophilus); 4) the position of glandular head (dorsomedian in $R$. histrio, ventromedian in $R$. ablegminus and ventrolateral in $R$. xerophilus).

DESCRIPTION. The species was described in detail by Szita, Logunov [2008].

DISTRIBUTION. Circum-Holarctic temperate range [Szita, Logunov, 2008; Helsdingen, 2013; Mikhailov, 2013; Nentwig et al., 2016].

HABITATS. Meadow grasses, neglected fields, sandy steppes, semi-deserts.

PHENOLOGY. The Crimea: $\bigcirc^{7} \sigma^{7}-\mathrm{IV}, \mathrm{VII}$,,++ V-VII, the peak activity of adults occurs in Jule and August (Fig. 25). Great Britain: $O^{7} \bigcirc-V-V I$ [Harvey et al., 2002]. Sweden: $\sigma^{7} \sigma^{7}-\mathrm{V}-\mathrm{VI}$, + + - V-VII [Almquist, 2006]. Czech Republic: $\sigma^{\top} \sigma^{7}-\mathrm{IV}$, , + IV-V [Bryja et al., 2005]. Russia: Perm Area: $\sigma^{\top} \sigma^{7}$ V, oo - VI-VII; Novosibirsk Area: $\bigcirc^{7} \bigcirc^{7}-\mathrm{V}-\mathrm{VI}$, OO — V-VII. Ukraine, Odesa Area: $O^{\top}+$ — VII. Kazakhstan: Pavlodar Area: $\bigcirc^{\top} \bigcirc$ - VI-VII; East Kazakhstan

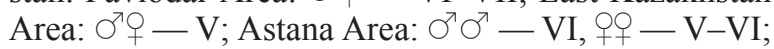
North Kazakhstan Area: $\sigma^{\top}+$ — VI [Szita, Logunov, 2008].

ACKNOWLEDGEMENTS. We thank V.N. Popov ( $\dagger$ ), G.V. Reutov (Simferopol), N.A. Stasyuk (Genichesk) and E.Yu. Sviridenko (Kiev) for providing us with some material used in this study. We thank P.E. Gol'din (Kiev) for improving the English of the earlier draft. Special thanks go to D.V. Logunov (Manchester) for commenting on the $\mathrm{ms}$ and editing the English of the final draft. 


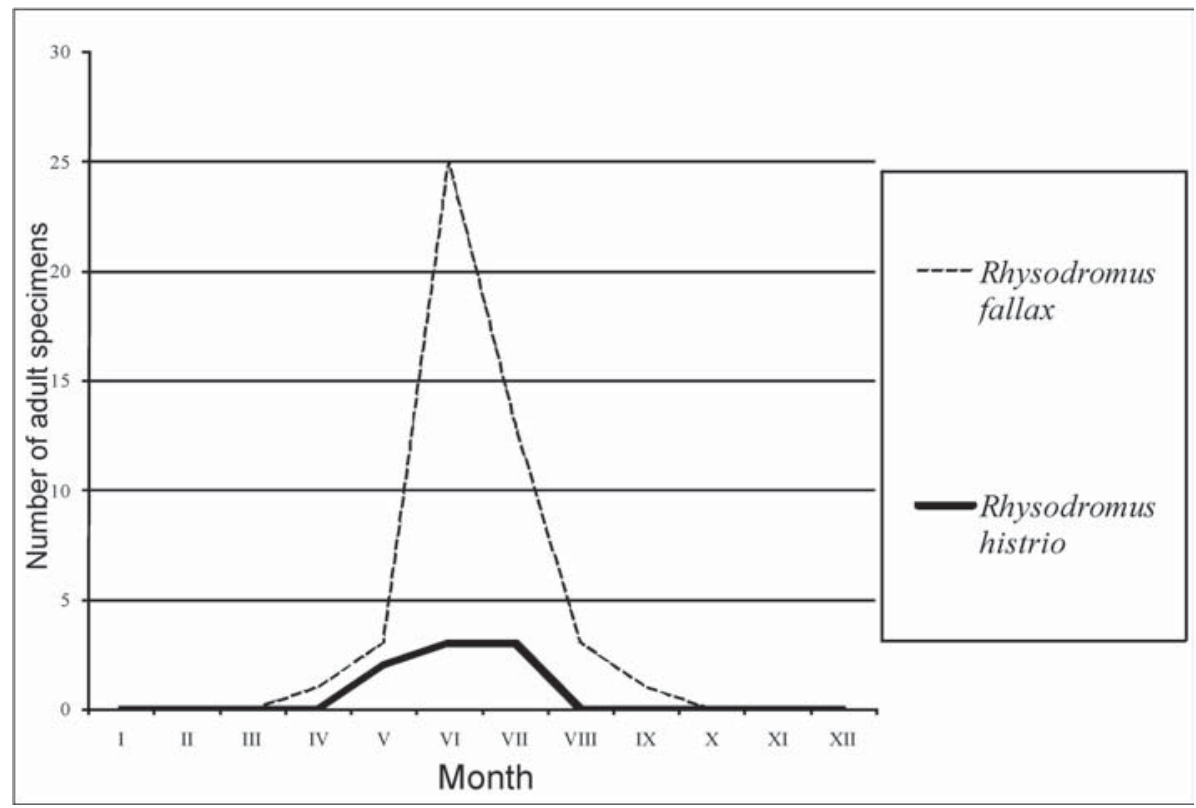

Fig. 25. Seasonal dynamics of adult activity of Rhysodromus fallax (Sundevall, 1833) and $R$. histrio (Latreille, 1819) in the Crimea based on the collected specimens.

Рис. 25. Сезонная динамика активности взрослых особей Rhysodromus fallax (Sundevall, 1833) и $R$. histrio (Latreille, 1819) в Крыму по материалам коллекции.

\section{References}

Almquist S. 2006. Swedish Araneae, part 2: families Dictynidae to Salticidae // Insect Syst. Evol., Suppl. No.63. P.285-601.

Bragina V.A. 1984. [Spiders fauna of Karadagh] // AN USSR Institut biologii yuzhnykh morei im. À.Î. Kovalevskogo. Karadagskoe otdelenie. Karadagskiy gosudarstvennyi zapovednik ÀN USSR. Letopis' prirody. T.1. Kniga.1. Chast'4. P.6468 [in Russian].

Bryja V., Řezáč M., Kubcová L., Kůrka A. 2005. Three interesting species of the genus Philodromus Walckenaer, 1825 (Araneae: Philodromidae) in the Czech Republic // Acta Musei Moraviae, Scientiae Biologicae. Vol.90. P.185-194.

Charitonov D.Å. 1932. Katalog der russischen Spinnen. AN SSSR. Leningrad: Izdadelstvo AN SSSR. 206 S. [in Russian and German].

Denis J. 1947. Results of the Armstrong College expedition to Siwa Oasis (Libyan desert), 1935. Spiders // Bulletin de la

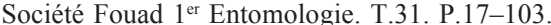

Dondale C.D., Redner J.H. 1975. The fuscomarginatus and histrio groups of the spider genus Philodromus in North America (Araneida: Thomisidae) // The Canadian Entomologist. Vol.107. P.369-384.

Harvey P.R., Nellist D.R., Tefler M.G. 2002. Provisional Atlas of British spiders (Arachnida, Araneae). Vol. 1-2. Huntington: Biological Records Centre. 406 pp.

Helsdingen P.J. 2013. Fauna Europaea: Araneae. http://www. faunaeur.org. (Version 2.6.2).

Kastrygina Z.A., Kovblyuk M.M. 2013. A review of the spider genus Thanatus C.L. Koch, 1837 in Crimea (Aranei: Philodromidae) // Arthropoda Selecta. Vol.22. No.3. P.239-254.

Kastrygina Z.A., Kovblyuk M.M. 2014. The spider genus Pulchellodromus Wunderlich, 2012 in the Crimea (Aranei: Philodromidae) // Arthropoda Selecta. Vol.23. No.3. P.279-283.

Kastrygina Z.A., Kovblyuk M.M. 2015. [The first record of species Rhysodromus omercooperi (Denis, 1947) (Aranei: Philodromidae) after its description] // Programma i materialy mezhdunarodnoi nauchnoi konferentsii, posvyashchyonnoi 50-letiyu Zoologicheskogo muzeya imeni M. I. Globenko Tavricheskoi akademii Krymskogo federal'nogo universiteta imeni V.I. Vernadskogo (Simferopol, 16-18 September 2015). Simferopol. P. 56-57 [in Russian].

Kovblyuk M.M. 2004a. [Catalogue of the spiders (Arachnida, Aranei) of the Crimea] // Voprosy razvitiya Kryma. Nauchnoprakticheskiy I diskussionno-analiticheskiy sbornik. Vyp.15. Problemy inventarizatsii krymskoi bioty. Simferopol: TavriyaPlus. P.211-262 [in Russian].

Kovblyuk M.M. 2004b. [Preliminary results of spiders fauna and biotopic distribution of spiders in Karadag Nature Reserve study] // National Academy of Sciences of Ukraine. Karadag Nature Reserve. Annals. T.20 (2003). P.139-145 [in Russian].

Kovblyuk M.M., Gnelitsa V.A., Nadolny A.A., Kastrygina Z.A. 2015. [Checklist of spiders (Arachnida, Aranei) of Karadag Nature Reserve] // A.V. Gayevskaya, A.L. Morozova (eds.). 100 years of the T.I. Vyasemsky's Karadag Scientific Station: issue of scientific papers. Simferopol: N.Orianda. P. 271-295 [in Russian].

Kovblyuk M.M., Kastrygina Z.A. 2015. [Updated catalogue of the spiders (Arachnida, Aranei) of the Crimea] // Ukrainska Entomofaunistyka. Vol.6. No.2. P.1-81 [in Russian].

Kovblyuk M.M., Kukushkin Î.V., Gnelitsa V.À., Nadolny À.À. 2008. [Brief atlas of spiders (Arachnida, Aranei) of Karadag Nature Reserve]. Simpheropol: N.Orianda. 120 pp. [in Russian].

Krasnobaev Yu.P. 2004. [Catalogue of spiders (Aranei) of the middle reaches of Volga River]. Samara: Zhiguli State Nature Reserve. 213 pp. [in Russian].

Logunov D.V., Huseynov E.F. 2008. A faunistic review of the spider family Philodromidae (Aranei) of Azerbaijan // Arthropoda Selecta. Vol.17. No.1/2. P.117-131.

Logunov D.V., Vazirianzadeh B., Moravvej S.A., Navidpour S. 2007. New faunistic records of the jumping and crab spiders (Aranei: Salticidae, Thomisidae and Philodromidae) from Iran // Arthropoda Selecta. Vol.15. No.3. P.225-228.

Mikhailov K.G. 1997. Catalogue of the spiders (Arachnida, Aranei) of the territories of the former Soviet Union. Moscow: Zoological Museum of the Moscow State University. 416 pp.

Mikhailov K.G. 1998. Catalogue of the spiders (Arachnida, Aranei) of the territories of the former Soviet Union. Addendum 1. Moscow: KMK Scientific Press Ltd. 50 pp. 
Mikhailov K.G. 2000. Catalogue of the spiders (Arachnida, Aranei) of the territories of the former Soviet Union. Addendum 3. Moscow: Zoological Museum, Moscow State University. $33 \mathrm{pp}$.

Mikhailov K.G. 2013. The spiders (Arachnida, Aranei) of Russia and abjacent countries: a non-annotated checklist // Arthropoda Selecta. Supplement No.3. Moscow: KMK Scientific Press Ltd. 262 pp.

Muster Ch. 2009a. Phylogenetic relationships within Philodromidae, with a taxonomic revision of Philodromus subgenus $\mathrm{Ar}$ tanes in the western Palearctic (Arachnida: Araneae) // Invertebrate Systematics. Vol.23. P.135-169.

Muster Ch. 2009b. The Ebo-like running crab spiders in the Old World (Araneae, Philodromidae) // ZooKeys. Vol. 16. P.47-73.

Muster Ch., Bosmans R., Thaler K. 2007. The Philodromus pulchellus-group in the Mediterranean: taxonomic revision, philogenetic analysis and biogeography (Araneae: Philodromidae) // Invertebrate Systematics. Vol.21. P.39-72.

Nentwig W., Blick T., Gloor D., Hänggi A., Kropf C. 2016. Spiders of Europe. www.araneae.unibe.ch. (Version 03.2016).

Paquin P., Dupérré N. 2003. Guide d'identification des Araignées (Araneae) du Québec // Fabreries. Supplement 11. 251 pp.
Schick R.X. 1965. The crab spiders of California (Araneae, Thomisidae) // Bulletin of the American Museum of Natural History. Vol.129. Article 1. P.1-180.

Spassky S.À. 1927. [Contribution to the spider fauna of Crimea] // Izvestiya Donskogo Instituta selskogo khozyaistva i melioratsii. Vol. 7. P.66-80 [in Russian].

Szita É., Logunov D. 2008. A review of the histrio group of the spider genus Philodromus Walckenaer, 1826 (Araneae, Philodromidae) of the eastern Palaearctic region // Acta Zoologica Academiae Scientiarum Hungaricae. Vol.54. No.1. P.23-73.

Urones C. 1986. La familia Philodromidae (Araneae) en el centrooeste de la Peninsula Iberica // Boletin Asoc. esp. Entom. Vol.10. P.231-244.

WSC 2016. World Spider Catalog. Natural History Museum Bern, online at http://wsc.nmbe.ch, version 17.0, accessed on 29.01.2016

Wunderlich J. 2012. Contribution to taxonomy and evolution of the european genera of the spider family Philodromidae (Araneae) // Beiträge zur Araneologie. Vol.7. P.25-56.

Responsible editor D.V. Logunov 